\title{
ATRX wt Allele
}

National Cancer Institute

\section{Source}

National Cancer Institute. ATRX wt Allele. NCI Thesaurus. Code C74977.

Human ATRX wild-type allele is located within Xq13.1-q21.1 and is approximately $281 \mathrm{~kb}$ in length. This allele, which encodes transcriptional regulator AT RX protein, is involved in the modulation of both transcription and chromatin structure. Mutations in the gene are associated with X-linked alpha-thalassemia/mental retardation syndrome, mental retardation syndromic X-linked with hypotonic facies syndrome type 1, and alphathalassemia myelodysplasia syndrome. 